\section{Michał Wojciechowski}

Uniwersytet Warmińsko-Mazurski, Olsztyn

m.wojciechowski@uwm.edu.pl

ORCID ID: 0000-0002-5658-7512

DOI: http://dx.doi.org/10.12775/BPTh.2019.001
Biblica

et

Patristica

Thoruniensia

12 (2019) 1: 25-41

ISSN (print) 1689-5150

ISSN (online) 2450-7059

\title{
Ethics in the Revelation of John
}

\section{Etyka w Apokalipsie Janowej}

\begin{abstract}
The Revelation of John implies and proclaims moral judgments, which is frequently overlooked. This subject has been studied recently, but we do not possess a satisfying synthesis. In the Revelation we can find some metaethical assumptions. The Revelation presents good and evil in a dualistic way, which implies the necessity of choice and of an adequate behavior ("works"), and further of the divine judgment. God and Christ are to be followed and our salvation depends on our actions, even if the perspective of punishment is not seen as a major motive of human deeds. There are also some ethical admonishments. The Law is not mentioned as authority, but some commandments of the Decalogue are indirectly quoted and keeping the commandments is praised. Ethical principles are frequently presented in the language of virtues and vices, as if under a Hellenistic influence; we also encounter good and bad examples of conduct. Social and political ethics of the Revelation is highly critical, condemning the empire stronger than any other biblical book. Some readers of the Revelation are disturbed by its violent images, but this can be explained by the use of the symbolic language of the apocalyptic genre and can be seen as an expression of necessity of justice and conversion.
\end{abstract}

Streszczenie. Apokalipsa Janowa zawiera w sobie i głosi sądy moralne, co jest często pomijane w badaniach naukowych. Ostatnio temat ten był przedmiotem rozważań, ale nie posiadamy jeszcze satysfakcjonującej syntezy tych badań. W Apokalipsie możemy znaleźć pewne założenia metaetyczne, a dobro i zło przedstawione są w sposób dualistyczny, co implikuje konieczność wyboru i odpowiedniego zachowania („uczynków”), a następnie Boskiego sądu. Należy naśladować Boga i Chrystusa, gdyż nasze zbawienie zależy od naszych działań, nawet jeśli perspektywa kary nie jest postrzegana jako główny motyw ludzkich czynów. Są też pewne upomnienia etyczne. Prawo nie jest wymieniane jako autorytet, ale niektóre przykazania Dekalogu są pośrednio cytowane i przestrzeganie przykazań jest chwalone. Zasady etyczne są częściej przedstawiane za pomocą języka cnót i wad, jakby pod wpływem hellenistycznym; napotykamy również dobre i złe przykłady postępowania. Etyka społeczna i polityczna Apokalipsy jest bardzo krytyczna, gdyż potępia imperium silniej niż jakakolwiek inna księga biblijna. Niektórzy czytelnicy Apokalipsy są zaniepokojeni jej gwałtownymi obrazami, ale można to 
wytłumaczyć użyciem symbolicznego języka typowego dla gatunku apokaliptycznego i wyrazem konieczności sprawiedliwości i nawrócenia.

Keywords: Revelation of John; biblical ethics; works; virtues and vices; violence.

Słowa kluczowe: Apokalipsa świętego Jana; etyka biblijna; uczynki; cnoty i wady; przemoc.

\begin{abstract}
$\mathbf{t} t$ the first glance, the Revelation of John does not seem to be a book of 1 - moral teachings. Some scholars, who oppose eschatology and ethics, openly deny that it contains any ethical concepts. The Revelation can lead, however, to moral conclusions, even if they are still ignored in the works of many scholars. ${ }^{1}$
\end{abstract}

However, the subject of the ethical dimension of the Revelation becomes appreciated - perhaps because virtually all the questions related to the Revelation of John have been already discussed by scholars looking for new fields of study. However, the only presentation that could be considered fairly complete, is the study of J. Kerner, which compares the ethics of the Revelation with 4 Esdras. $^{2}$ I have touched this question in the paper written in Polish ${ }^{3}$ and some further studies have brought important partial contributions. ${ }^{4}$

The ethics of the Revelation is presented sometimes in articles and in chapters of books on New Testament ethics; ${ }^{5}$ less frequently in the monographs on related subjects and in the introductions to the commentaries, where it is treated briefly. The authors approach the question of ethics from different angles. In this article, I shall try to give an overview of this field, namely an overview of the problem, and not of the scholarly positions.

Ethical teaching can be understood more narrowly, as moral admonishments directed to the individuals, a set of commandments (presented directly or indirectly), and more widely, as any evaluations of human behavior. In this second meaning, ethics covers such aspects as political opinions implied by the

1 In a recent commentary we read about "der Mangel an ausformulierter Ethik in der Apk" (K. Berger, Apokalypse, 132).

2 J. Kerner, Die Ethik.

3 M. Wojciechowski, Etyka. Shorter presentation in: M. Wojciechowski, Apokalipsa.

4 G. Carey, The Apocalypse; T. Holtz, Die «Werke»; H.E. Lona, „Treu bis zum Tod“; J.A. du Rand, Y.M. Song, The Ethos; K. Scholtissek, 'Mittelhaber an der Bedrängnis; U. Vanni, Postawa chrześcijanina; M. Wolter, Christliches Ethos.

5 Cf. e.g. O. Prunet, La morale chrétienne; H.-D. Wendland, Ethik; W. Schrage, Ethik; R. Schnackenburg, Die Sittliche Botschaft; R.B. Hays, The Moral Vision. 
Revelation, other questions related to social ethics, images of violence and even existential attitudes. ${ }^{6}$ It covers also instructions for the Christian life contained in the chapters 2 and 3. Discussing ethics, we should also remember about the ethos of this book, the models of behavior suggested for the Christian community and/or the self-portrait of the author as an authority and example for the reader.

We should further discern between the opinions of the author of the Revelation himself, and the results of their confrontation either with the theological conclusions derived from the Bible as a whole, or with some judgments which modern people would be inclined to formulate in relation to the contents of the Revelation. Only the first category belongs fully to the ethical doctrine of the book. However, we may and should compare the ethics of the Revelation with other biblical or non-biblical sources. The multiform reception of the Revelation must be remembered as well.

On the other hand, applying our present vision of morals to the doctrine of the Revelation can be misleading. This danger threatens especially the authors writing about politics, justice and violence in the Revelation, who often tend to be inspired by modern ideologies and problems, especially in their choice of the hermeneutical principles. Discussion about Revelation in the context of liberation, oppression, feminism, and so on, often reduces this ancient book to the role of a quarry where we pick selected stones.

Other apocalyptic works also contain moral teaching. Comparisons with Revelation are possible and fruitful (e.g. with 4 Esra, with 1 Hen). It would, however, exceed the limits of this article.

\section{Situation of human beings and its ethical implications}

The worldview of the book of Revelation is dualistic. This dualism has primarily moral features as good and evil are at war. ${ }^{7}$ The sinners and their fate are contrasted with the innocent and saved. The righteous suffer because of persecutions, often as martyrs; through suffering they go to victory, per aspera ad astra (Rev 12.11). The evildoers suffer of plagues and are finally destroyed. There is no intermediate possibility. The book presupposes and prescribes clear choices: Let the evildoer still do evil, and the filthy still be filthy, and the righteous still do right, and the holy still be holy (Rev 22.11; cf. 3.15-16).

6 As manifested by the title: K. Wengst, „Wie lange noch?” Schreien nach Recht und Gerechtigkeit. Cf. B. Widła, Antropologia.

7 Cf. especially J. Nowińska, Motyw wojny. Cf. also A. Satake, Kirche. 
Such a vision of the moral world, strongly black and white, is contradicted by the everyday experience, proving that humans are most often morally grey. The same criticism applies to many other biblical texts, as the parable of the Last Judgment and other sayings of Jesus (Matt 25.31-46; cf. further 7. 16-17,24-27; 12.35; 22.1-13 parr.; 25.1-13 cf. Mark 4.3-9,14-20 parr.; Luke 16.19-31). Therefore this image should not be explained as a factual description, but as an ethical model. It would have two functions. First, it shows the fundamental difference between good and evil, stated in many biblical texts (cf. e.g. Deut 30.15,19-20; Amos 5.14; Isa 5, 20). Next, it is an appeal for the correct choice and moral instruction associated with a pedagogical warning.

Hence the importance of the conversion, as an answer to human weaknesses, mentioned 12 times (verb metanoein). ${ }^{8}$ The appeal to convert is addressed to the Christians, because they $\sin$ (the notion of $\sin$ is treated as obvious). Hence we could understand it as a "second conversion". The evildoers are supposed to refuse conversion ( $\operatorname{Rev} 2.22 ; 9.20-21 ; 16.11)$. Greek metanoein refers to a change of mind, but the Semitic counterparts - to a change of behavior (Hebrew shub). All that implies some action, and not only a decision; there is no victory without fight.

Therefore, the Revelation often speaks about works (ergon/erga, occurring 20 times) - in line with James, not with Paul. Works express the attitude and value of human beings, their essential quality. Humans will be judged according to their works: The dead were judged by what was written in the books, by what they had done (Rev 20.12-13; cf. 2.23; 14.13: their works follow them). However, as "faith" in Paul means "faithfulness" and implies ethical behavior, "works" in the Revelation of John designate some moral actions, good or evil (Rev $2-3$; cf. 16.11; 18.6; 19.8; 21.22), but also imply the close relation to Jesus Christ as savior (Rev 2-3; cf. 7.14). These works are works of men already freed from the sin by his blood ( $\operatorname{Rev} 1.5)$. They are no more slaves of the beast, they are free to choose and to act according to the rules of love and faith (Rev 2.19).

The specific feature of the Revelation is the idea of participation. ${ }^{9}$ It suggests a collective aspect of ethics: an individual in the context of the interpersonal relations. I John, your brother, who share with you in Jesus the tribulation and the kingdom and the patient endurance (Rev 1.9). The faithful are fellow workers. They expect martyrdom (Rev 6.11) and they are to share in the victory and kingdom of the Lamb (Rev 3.21; 21.7; cf. 1.6; 5.10). Moreover, God is holy (hagios) and the saved are holy, which suggests a participation in His moral

8 Cf. especially R. Rubinkiewicz, Nawrócenie.

9 Scholtissek, Mittelhaber an der Bedrängnis. 
qualities. On the other hand, the participation in other people's sins should be avoided (Rev 18.4).

\section{Divine actions and their ethical implications}

The motivation of ethics is not quite explicitly presented in the Revelation, but it seems that it should be found in the relation of human beings to God and Christ. It corresponds to the general stance of the Bible, where God and Christ are the example to follow, the source of moral law and the goal of moral life. Accordingly, the evildoers are motivated by a relation to false gods and diabolic forces.

The Revelation does not refer to the divine Law, Torah, as a moral authority. Perhaps for the author this authority is replaced by the revelation of Christ through his prophet, as it is suggested by Rev $22.18-19$ which attributes to the prophecy the dignity given to the Law by Deut 4.2; 13.1 (12.32 LXX); 29.19-20. However, some of these elements are presupposed, namely the commandments to be kept (Rev 12.17; 14.12; cf. Sir 29.1), together with general notions as justice, sin, works, purity (Rev 14.5 cf. 21.27; 22.11,15), holiness (Rev 14.12; cf. 5.8; 7.3 etc.). We shall mention later some particular commandments. Therefore, the basic content of the Law is presupposed. In conclusion, the commandments result from the divine will, but the law as a whole does not function as an ultimate reason for the ethics.

Keeping the commandments is paired with the testimony of Jesus and faith: Those who keep the commandments of God and bear testimony to Jesus (Rev 12.17; cf. 14.12). It could be possibly understood in the distributive manner: the commandments for Israel and the relation with Jesus for his people, but more likely the saved of the Revelation are both Israel and the Church, they keep both commandments and faith.

There are some hints that Christ is conceived as moral example and source of ethics. He is the source of the revealed truth (Rev 1.1) and its witness (Rev $1.5 ; 3.14 ; 19.11)$; seven letters from Rev $2-3$ are presented as his speech. Therefore, moral admonitions in the book of Revelation should be treated as words of Christ. Occasionally, the saved are mentioned as followers of Christ: in his victory (Rev 3.21), in his way (Rev 14.4), in his martyrdom (cf. Rev 5.4,12; 13.8 with 6.9). The concept of imitatio Christi seems to be known to the author of the book. Further, the saving action of Christ makes holiness possible: Who loves us and has freed us from our sins by his blood and made us a kingdom, priests to his God and Father (Rev 1.5-6; cf. 5.9-10). We should love because we are to meet the Loving One (cf. 1 John 4.19). 
Biblical eschatology has moral implications. This principle need not to be conceived narrowly, in the sense of the interim ethics, interpreted as special, maximalist moral expectations related to the imminence of the end. New Testament eschatology states that humans are to meet Christ and be judged. Whether it happens in the present or in the future, it should change our moral life. We should keep the faith in Christ (Rev 2.13), become rich (Rev 3.17), keep our garments clean for the day (Rev 16.15). Keeping the commandments, mentioned above, has a soteriological context. The divine judgment according to the works makes our moral actions essential for our salvation. We are to expect justice, not tolerance. Whatever we do, we should consider the end. Respice finem (cf. Sir 7.36).

It is worth stressing that the plagues falling on the evildoers and the salvation of the righteous are not presented simply as motives of moral behavior. Punishment and reward seem to be first of all consequences of good and evil, consequences necessitated by the justice of God. In particular, the punishment does not make people to convert: The rest of mankind, who were not killed by these plagues, did not repent of the works of their hands nor give up worshiping demons and idols of gold and silver and bronze and stone and wood, which cannot either see or hear or walk; nor did they repent of their murders or their sorceries or their immorality or their thefts (Rev 9.20-21; cf. 16.11).

However, these good or bad consequences indirectly realize the importance of the ethics. Threats and consolations in the Revelation possess a pedagogical dimension, they facilitate the good choice (similarly as some conclusions of the parables of Jesus). We have just mentioned the refusal to convert, but the Revelation prefers positive suggestions to threats. A good example is the final vision ( $\operatorname{Rev} 21.1-22.5$ ), where only two verses mention punishments (Rev $21.8,27)$. According to Kerner, ${ }^{10}$ we can list in the body of the book three times more verses with the positive motivations than with the negative ones.

Similar remarks can be formulated in relation of the moral behavior to the present glory (or sufferings) and to the expected end. Apart from the final chapters 21-22 we find futuristic motivation only in five verses (Rev 1.3; 3.3,11.20; 16.15), and present ones in nearly forty verses. All this contradicts the popular opinion on the Revelation as gruesome and eschatological. The author prefers present and positive connotations for ethics, its relation to the salvation - even if he clearly shows the possibility of punishment. I would say that it is both good theology and good psychology.

10 Kerner, 124. Cf. also T. Collins, Apocalypse 22:6-21. 


\section{Individual commandments}

The commandments of the Decalogue (Ex 20.1-17 parr.) are not quoted, but they find some reflection in the Revelation, except for the second, the fourth and the ninth one (in the Catholic order). You shall have no other gods before me is supposed in the appeals to faith, endurance and love to God and Christ (Rev 2.4); idolatry is clearly condemned (Rev 9.20; cf. 2.14.20; 21.8): you shall not make for yourself a graven image. The opposition to the Roman state cult (see further) is also associated with this commandment. Remember the sabbath day, to keep it holy, is perhaps alluded to in Rev 1.10 on the Lord's day and further in the many scenes of worship.

You shall not kill can be found in the condemnation of murder and of murderers, found in the lists of vices from Rev 9.21; 21.8; 22.15 (cf. Rev 18.24 on 'Babylon' and other texts expressing solidarity with the killed). You shall not commit adultery is presupposed in the condemnation of prostitution (Rev $9.21 ; 21.8 ; 22.15$ once more; cf. $2.14,20 ; 17.1-5)$, even if porneia discerns from moicheia and these texts do not allude to marriage. You shall not steal is reflected in the mention of the thefts in Rev 9.21. You shall not bear false witness stands behind the strong condemnation of the lies and liars, found in Rev $14.5 ; 21.8,27 ; 22.15$ (cf. Rev $2.2 ; 3.9 ; 16.13 ; 19.20 ; 20.10$ ). Lie is not conceived as just an occasional sin from the everyday life, but as an attitude of denying God, truth and salvation. You shall not covet can be associated with the criticisms of the desire for material goods in Rev 18 (epithumia secondarily in Rev 18.14).

The author of the Apocalypse had known the significance of the commandments (cf. Rev 12.17; 14.12). It seems that he took them in their wider meaning; they were applied to similar situations, in line with the interpretation of the commandments found in the first century. However, as no commandment is directly quoted, it was not his favorite subject. He preferred not to proclaim norms, but to show virtues and vices: looking for commandments, we have found them instead. It is not so typical for the Bible, and nearer to the Hellenistic style of moral teaching. Nevertheless the contents of moral appeal of the Revelation is fully in line with the general stance of the Bible.

\section{Virtues and vices}

Only one text in the Revelation can be interpreted as a list of virtues: I know your works, your love and faith and service and patient endurance (Rev 2.19; 
overlooked by some authors ${ }^{11}$ ). "Works" on this list indicate that any virtues (or vices) are not static qualities, but they find their fulfillment in the corresponding moral actions. Love, agape, is placed first. This fact and the association with faith suggest some relation with the Pauline teaching. "Faith, hope and love" (1 Cor 13.13; other variants in 1 Thess 1.3; 5.8; Rom 5.1-5; Col 1.4-5) is more known, but Paul joined also two of them, precisely faith and love (1 Thess 3.6; 2 Thess 1.3; Gal 5.6). In the Revelation, Christ loves (Rev 1.4; 3.9; cf. 20.9) and human beings should love (Rev 2.4.19). Faith, pistis, is found in the above enumeration on the second place, after love. It seems to direct this love to God and Christ, whereas service, diakonia, to the fellow men. Patient endurance, hupomone, found last, accentuates that the moral attitude should be steadfast despite obstacles. ${ }^{12}$ Hupomone is found more often in relation to persecutions ( $\operatorname{Rev} 2.2,3,19 ; 3.10 ; 13.10$ - with faith; 14.12). This attitude is described also with such verbs as "keep" and "watch" (terein, kratein, gregorein).

We find further three catalogues of vices. It confirms that the genre of virtues/vices list, common in the moral exhortation of the New Testament and in its times, is present in the Revelation. In Rev 9.20-21 the vices of the mankind refusing conversion are listed: idolatry (developed), murders, sorceries, fornication, thefts. In Rev 21.8 we read about the condemned for fire and second death: cowardly, faithless, polluted, murderers, fornicators, sorcerers, idolaters, liars. In Rev 22.15 about those outside: dogs, sorcerers, fornicators, murderers, idolaters, false ones.

These vices are obstacles to salvation. However, they are not of the same weight. The first list represents a planned order, beginning from the heaviest sin, idolatry. Two other lists lack order. They mention concrete sins, but also attitudes (cowards, faithless - perhaps apostates) or their results (polluted; "dogs" are polluted pagans in general or homosexuals). As I have mentioned before, lie and falsehood refer not to single false statements, but to denying God, Christ and truth.

The differences between these lists and their ostensive rhetorical character indicate that they are not conceived as definitive catalogues. They are rather attempts to paint the portrait of the exemplary evildoer, lacking any virtue, condemned to perish. They are to be interpreted in a collective manner, as sketchy portraits of one, great, multifaceted mortal sin. Nevertheless, we should not go so far as to interpret all these vices as reflections of Roman idolatry (cf. Wis 14.27).

11 O. Böcher, Lasterkataloge; H.Giesen, Lasterkataloge. General literature: A. Vögtle, Die Tugend- und Lasterkataloge; S. Wibbing, Die Tugend- und Lasterkataloge.

12 Cf. S. Pisarek, Cierpliwa wytrwałość. 
I have already mentioned that the Revelation has a pendant towards an artificial, overstated moral dualism. We are not far from the stoic idea that human beings can be either noble sages or villains; for the stoics who has one vice, has all of them (Areios Didymos in Stobaios, 2.7.11k). However, the goal of the author is not doctrinal, but didactic. These lists are not tariffs (which trespasses make you condemned), but warnings (what you should avoid) and they should lead to conversion.

Apart from these programmatic texts, some virtues and vices are also mentioned or suggested elsewhere in the Revelation. Hope and courage are not mentioned directly, but their role is appreciated. They make possible endurance among persecutions and plagues, and finally martyrdom. They cannot be dissociated from fight and victory. Humility is not directly mentioned, either, although it is occasionally presupposed as virtue ( $\operatorname{Rev} 3.17$ ). It is suggested together with poverty, whereas the rich, idolatrous and murderous are criticized (Rev $6.6 ; 13.16-17 ; 18$ ). The vices of pride and arrogance (hubris) are supposed by Rev 13 and 17 .

\section{Examples of good and bad conduct}

As many biblical books, the Revelation contains moral examples. They are neither given preeminent place nor pointed with a finger, as in the didactic novels, but they are clearly discernible. Even with barely basic knowledge of ethics they could be identified, because good and evil are completely different. Paradigmatic persons and their behavior have both religious and moral features. In this respect, the Revelation is comparable to other biblical books.

At the beginning, Christ himself is a faithful witness (Rev 1.5; cf. Rev 3.15; $19.10 ; 22.16-20)$. Later we the meet Antipas (Rev 2.12), followed by other witnesses and martyrs (Rev 6.9; 11.3-12; 12.11,17; 17.6; 20.4). In the Revelation, to be faithful even to death is a moral ideal (Rev $12.11 ; 13.10)$. Moreover, "through a chiastic structure it exhorts the audience to follow the example of Christ to martyrdom in order to obtain the promised resurrection". ${ }^{13}$

Further, Antipas is contrasted with pretended Christians, prone to idolatry and adultery, or such ones who are too tolerant to sin and sinners (Rev 2-3). The saved are contrasted with the unrepentant sinners. Beasts, Babylon and their servants are contrasted with new Jerusalem. The reader can easily identify examples to follow and to avoid. 
The self-presentation of John has an exemplary function as well. He acts in the role of a courageous prophet and witness ( $\operatorname{Rev} 1.2$; cf. $\operatorname{Rev} 22.6$ ), of a careful pastor of his congregation (Rev 2-3), but also of a partner of his audience (Rev 1.5-6,9). They are invited to share in him and to follow his message.

\section{Political ethics}

The Revelation was written in the context of persecution. Large sections of this book contain its symbolic representation (Rev 11-13; 17-18; cf. Rev 2.13). Even if the author meant the Roman empire as the main enemy, he gave to it some universal features, allowing to apply these texts to any similar empires. It is open to question how far these persecutions were real, and how far imaginary or expected. Nevertheless, they have generated a strong condemnation of the state and of state religion. Social and political ethics of the Revelation is highly critical and this matter has been widely studied. ${ }^{14}$

If we compare these texts with the prophetic condemnations of foreign rulers, the Revelation goes even further. There is no question of God using empires as his tools, no question of the conversion or any regret of the evil ruler. On the other hand, the Revelation does not propose an armed uprising, as Maccabees, or one violent act, as Judith, leaving judgment to the holy God who will make the satanic empire fall.

Roman state is presented first as "Beast" (Rev 13; cf. Dan 7). Its power comes from the Dragon, or Satan (Rev 12.9). During this eon, called "forty two month" (half of the period of seven years), the empires rule this world, blaspheming God, conquering the saints and making all the people worship the beast (Rev 13.1-8). The second beast, identified later with the false prophet (Rev 19.20), represents imperial religion and ideology with their messianic pretences. The capital of the empire is presented as a great whore and Babylon (Rev 17), condemned to destruction (Rev 18). It appears as an epitome of idolatry, cruelty, prodigality and debauchery.

Godless and cruel state is condemned in every respect. It will be annihilated in fire together with its allies ( $\operatorname{Rev} 19.19-21)$. As for the faithful, they should abstain from any participation in the empire ( $\operatorname{Rev} 18.4$ ), although it tries to mark everybody as its own (Rev 13.16-17). It seems as well that the reality of

14 Cf. e.g. P. Abir, Bible and the State; P.A. Abir, A Theology of Protest; C. Bedriñán, La dimensión socio-política; G. Carey, Symptoms; S.T. Monera, The Christian's Relationship; O. O’Donovan, The Political Thought; W.E. Pilgrim, Uneasy Neighbors; E. Schüssler Fiorenza, Babylon the Great; T. Söding, Heilig. 
the empire covers not only the political and religious power, but also resulting social oppression and economic exploitation.

\section{Problem of violence}

The visions of the Apocalypse are full of violence and revenge. This fact has been often discussed by scholars ${ }^{15}$ who represent basically two attitudes. Some modern readers are more or less scandalized by such texts and they reject them. However, others recognize the problem but seem to approve the violent language as a protest against evil and oppression, especially in the political sphere. ${ }^{16}$

The first position does not belong to the exegesis, because it has its sources outside the biblical book. It can represent an approach of biblical theology, confronting the Revelation with biblical texts about love, forgiveness etc. It may also reflect modern tastes, related more or less to the non-violence ideology.

The correct answer, however, has to be based on the exegesis. It seems that the imagery of the Revelation is largely conventional and the mentions of catastrophes and blood do not mean that the author is revengeful and blood-thirsty, because they belong to the language of the genre. God conquers and destroys the forces of evil and therefore military images are used, but they should not be perceived in the literalistic manner. Warrior kills by means of a sword from his mouth: through his word, and not by his arm (Rev 19.21). Victory comes in the liturgical setting and the fight is spiritualized.

If humans are to abstain from revenge, it is because justice and punishment belong to God, who is holy and just (Rev 16.5-7). The saved of the Revelation do not participate directly in war, but suffer martyrdom. God himself stands for the oppressed and acts against evil, as he is supposed to avenge them (Rev 6.9-10; 19.2; Greek ekdikesis - ekdikein), whereas divine punishment should make the guilty convert.

The next point is that in the biblical thought the first cause, God, often replaces secondary causes; it is a philosophical touch in the biblical worldview. Therefore, cosmic and natural catastrophes are presented as divine actions. Finally, in the Revelation we meet also evil things caused by the dragon, the beasts and their servants.

15 W. Klassen, Vengeance; R.A. Spencer, Violence; G. Biguzzi, “L'Apocalisse; D.L. Barr, Doing Violence; I. Boxall, Violence. Review of research: R. Skaggs, T. Doyle, Violence.

16 Wengst, Wie lange noch? 
Nevertheless, some difficulty remains, even after these clarifications. On the level of imagery, the Revelation could possibly incite men to aggression and violence, and to holy wars. We find here an old problem of the biblical interpretation: morally dubious biblical texts. ${ }^{17}$

The presence of violent expressions in the Revelation, a late book, exclude the popular "evolutionary" solution of this problem that such troublesome texts are to be related with the earlier stages of the development of the scriptural teaching. We should, instead, make an appeal to the "holistic" approach, associating the truth and the infallibility of the Bible with the canon as a whole (pasa graphe in 2 Tim 3.16), whereas the truth of the particular sentences can be only partial. In the case of the Revelation, violent phrases help to identify the evil and show that a passive pacifism is not a sufficient solution as anger can be justified.

It leads to the second approach, the approval of the inspired protest against oppression. The Revelation presupposes, indeed, the situation of persecution. Are we correct treating the language of the Revelation as an adequate expression of anger? It seems that such an answer is too dependent on our modern perspective. This anger can be justified on the psychological level and perhaps on the social level (if we accept the ideology of revolutionary liberation). But what about theology? We encounter here another classical moral problem whether violent means are sometimes morally justified. Let me suggest that the Bible as a whole does not give a definite answer to the question "to fight or not to fight".

\section{Bibliography}

\section{a) Selected commentaries}

Aune D.E., Revelation, vol. 1-3, Word Biblical Commentary 52A-C, Dallas 1997-98. Beale G.K., The Book of Revelation (NIGTC), Grand Rapids-Carlisle 1999 (shorter version 2015).

Berger K., Apokalypse des Johannes, Teilband 1-2, Freiburg/Br. 2017.

Ford J.M., Revelation, Anchor Bible 38, Garden City 1975.

Giesen H., Die Offenbarung des Johannes, Regensburger Neues Testament, Regensburg 1997.

Harrington W.J., Revelation, Sacra Pagina 16, Collegeville 1993.

Holtz T., Die Offenbarung des Johannes, Das Neue Testament Deutsch 11, ed. K.-W. Niebuhr, Göttingen 2008.

17 Cf. e.g. W. Davies, The Morally Dubious; M. Wojciechowski, Etyka, 275-287. 
Jankowski A., Apokalipsa świętego Jana. Wstęp - przekład z oryginału - komentarz, Pismo Święte Nowego Testamentu 12, Poznań 1959.

Koester C.R., Revelation, Anchor Yale Bible 38, 2014.

Kovacs J., Rowland C., Revelation. The Apocalypse of Jesus Christ, Blackwell Bible Commentaries, Oxford 2004.

Malina B.M., Pilch J.J., Social-Science Commentary on the Book of Revelation, Minneapolis 2000.

Müller U.B., Die Offenbarung Johannes, Ökumenisches Taschenbuch Kommentar zum Neuen Testament 19, 2nd ed., Gütersloh 1995.

Osborne G.O., Revelation, Baker Exegetical Commentary on the New Testament, Grand Rapids 2002 (simpler version 2016).

Ostański P., Objawienie Jezusa Chrystusa, praktyczny komentarz do Apokalipsy, Ząbki 2005.

Prigent P., L'Apocalypse de saint Jean, Commentaire du Nouveau Testament $14,2^{\text {nd }}$ ed., Génève 2000.

Satake A., Die Offenbarung des Johannes, Kritisch-Exegetischer Kommentar 16, Göttingen 2008.

Strack H.L., Billerbeck P., Kommentar zum Neuen Testament aus Talmud und Midrasch, vol. 3: Die Briefe des Neuen Testament und die Offenbarung Johannis, München 1926.

Strecker G., Schnelle U. (ed.), Neuer Wettstein. Texte zum Neuen Testament aus Griechentum und Hellenismus, vol. 2, Texte zur Briefliteratur und zur Johannesapokalypse, Berlin 1996.

Weinrich W.C. (ed.), Revelation, Ancient Christian Commentary on Scripture. NT 12, Downers Grove 2005.

Wojciechowski M., Apokalipsa świętego Jana, Nowy Komentarz Biblijny. Nowy Testament 20, Częstochowa 2012.

\section{b) General works}

Bretzke T.J., Bibliography on Scripture and Christian Ethics, Studies in Religion and Society 39, Lewiston et al. 1997.

Davies E.W., "The Morally Dubious Passages of the Hebrew Bible: an Examination of Some Proposed Solutions," Currents in Biblical Research 3(2005)2,197-228.

Hays R.B., The Moral Vision of the New Testament: A Contemporary Introduction to New Testament Ethics, Edinburgh 1996.

Pisarek S., Cierpliwa wytrwałość: „Hypomone”, „Hypomonein” w Nowym Testamencie, Katowice 1992.

Sanders J.T., Ethics in the New Testament, Philadelphia-London 1975.

Schnackenburg R., Die Sittliche Botschaft des Neuen Testaments, Freiburg/Br et al. 1986-88.

Schrage W., Ethik des Neuen Testaments, Göttingen 1982. 
Vögtle A., Die Tugend- und Lasterkataloge im Neuen Testament, Neutestamentliche Abhandlungen 16/4-5, Münster 1936.

Wibbing S., Die Tugend- und Lasterkataloge im Neuen Testament und ihre Traditionsgeschichte unter besonderer Berücksichtigung der Qumran-Texte, Beihefte zur Zeitschrift für die neutestamentliche Wissenschaft 25, Berlin 1959.

Widła B., Antropologia egzystencjalna Apokalipsy Janowej, Warszawa 1996.

Wendland H.-D., Ethik des Neuen Testaments, Göttingen 1970.

Wojciechowski M., Biblia o państwie, Kraków 2008.

Wojciechowski M., Etyka Biblii, Kraków 2009.

\section{c) Studies}

Abir P., "Bible and the State. A View from the Apocalypse of John," Bible Bhashyam 31, 1(2005), 38-67.

Abir P.A., "A Theology of Protest in the Book of Revelation," Indian Theological Studies 33, 1(1996), 43-53.

Barr D.L., “Doing Violence. Moral Issues in Reading John's Apocalypse”, in: Barr D.L. (ed.), Reading the Book of Revelation. A Resource for Students, SBL Resources for Biblical Study 44, Atlanta 2003, 97-108.

Barr D.L., "Towards an Ethical Reading of the Apocalypse. Reflexions on John's Use of Power, Violence, and Misogyny," in: SBL 1997 Seminar Papers, Atlanta 1997, 358-367.

Bauckham R.J., “The Economic Critique of Rome in Revelation 18," in: The Climax of Prophecy. Studies in the Book of Revelation, Edinburgh 1993, 338-383.

Bedriñán C., La dimensión socio-política del mensaje teológico del Apocalipsis, Roma 1996.

Biguzzi G., "LApocalisse e le spirito di vendetta," Euntes Docete 55(2002)1, 45-61.

Böcher O., Lasterkataloge in der Apokalypse des Johannes, in: Leben lernen im Horizont des Glaubens, Fs. S. Wibbing, ed. B. Buschbeck, F. Lemke, Landau 1986, 75-84.

Boxall I., "Violence in the Apocalypse," Scripture Bulletin 35(2005)2, 73-84.

Broadhead E.K., "Sacred Imagination and Social Protest", Review and Expositor 98, 1(2001), 77-85.

Campbell W.G., Apocalypse et extermination, Revue Reformée 54(2003), 89-107.

Carey G., "Symptoms of Resistance in the Book of Revelation," in: The Reality of Apocalypse..., ed. D.L. Barr, 169-180.

Carey G., "The Apocalypse and Its Ambiguous Ethos," in: Moyise S. (ed.), Studies in the Book of Revelation, Edinburgh-New York 2001, 163-180.

Collins T., Apocalypse 22:6-21 as the Focal Point of Moral Teaching and Exhortation in the Apocalypse, Roma 1986.

Collins T., "Moral Guidance in the Apocalypse," Emmanuel 95(1989), 502-509.

Cruz V.P., The Beatitudes of the Apocalypse. Eschatology and Ethics, in: Perspectives on Christology, Fs. P.K. Jewett, ed. M. Shuster, R. Muller, Grand Rapids 1991, 269-283. 
D'Souza J., Power, Violence and Suffering in the Book of Revelation. A Contextual Reading, diss. Gregorianum, Roma 2002.

Giesen H., "Lasterkataloge und Kaiserkult in der Offenbarung des Johannes, w: Studien zur Johannesoffenbarung und ihrer Auslegung," Fs. O. Böcher, eds. F.W. Horn, M. Wolter, Neukirchen 2005, 210-231.

Holtz T., "Die "Werke » in der Johannesapokalypse, in: Geschichte und Theologie der Urchristentums. Gesammelte Aufsätze," Wissenschaftliche Untersuchungen zum Neuen Testament 57, ed. E. Reinmuth, C. Wolff, Tübingen 1991, 347-361.

Humphrey E.M., "The Sweet and the Sour: Epics of Wrath and Return in the Apocalypse," in: SBL 1991 Seminar Papers, Atlanta 1991, 451-460.

Kerner J., "Die Ethik der Johannes-Apokalypse im Vergleich mit der des 4. Esra. Ein Beitrag zum Verhältnis von Apokalyptik und Ethik," Beihefte zur Zeitschrift für die neutestamentliche Wissenschaft 94, Berlin 1998.

Klassen W., "Vengeance in the Apocalypse of John," Catholic Biblical Quarterly 28(1966), 300-311.

Lee M.V., "A Call to Martyrdom. Function as Method and Message in Revelation," Novum Testamentum 40(1998)2, 164-194.

Lempa H., "Motyw walki dobra i zła w Apokalipsie św. Jana (Ap 12-20)," in: Z zagadnień dobra i zła według Biblii, Fs. H. Langkammer, ed. J. Flis, Lublin 1990, 167-180.

Lona H.E., “"Treu bis zum Tod». ... Ethos des Martyriums in der Offenbarung des Johannes," in: Neues Testament und Ethik, Fs. R. Schnackenburg, ed. H. Merklein, Freiburg 1989, 442-461.

Luz U., "Absolutheitsanspruch und Aggressionspotenzial im frühen Christentum," Evangelische Theologie 64(2004)4, 268-284.

Monera S.T., "The Christian's Relationship to the State according to the New Testament: Conformity or Non-conformity?” Asia Journal of Theology 191(2005)1, 106-142.

Münchow C., Ethik und Eschatologie. Ein Beitrag zum Verständnis der frühjüdischen Apokalyptik mit einem Ausblick auf das Neue Testament, Göttingen 1981.

Murphy F.J., "The Book of Revelation, Currents in Research.” Biblical Studies 2(1994), p. 181-225.

Neal B.S., The Concept of Character in the Apocalypse with Implications for Character Education, Washington D.C. 1983.

Nowińska J., "Motyw wojny dobra ze złem w Apokalipsie św. Jana”, Rozprawy i Studia Biblijne 27, Warszawa 2006.

O'Donovan O., “The Political Thought of the Book of Revelation," Tyndale Bulletin 37(1986), 61-94.

Peters O.K., Politics of Violence in the Apocalypse of John. Moral Dilemma and Justification, SBL Meeting 2004, 18 pages.

Pilgrim W.E., Uneasy Neighbors. Church and State in the New Testament, Minneapolis 1999. 
Popielewski W., "Pojęcie kłamstwa w Księdze Apokalipsy," in: „Bóg jest miłością” (1J 4,16), Fs. J. Kudasiewicz, ed. W. Chrostowski, Rozprawy i Studia Biblijne 25, Warszawa 2006, 333-354.

Prunet O., La morale chrétienne d’apres les écrits johanniques, Paris 1957.

Rand du J.A., Y.M. Song, "The Ethos of the Book of Revelation," Verbum et Ecclesia 24, 2(2003), 374-395.

Royalty R.M., The Streets of Heaven. The Ideology of Wealth in the Apocalypse of John, Macon 1998.

Rubinkiewicz R., “Nawrócenie i pokuta w Księdze Apokalipsy św. Jana,” Roczniki Teologiczno-Kanoniczne 43(1996)1, 149-160.

Satake A., "Kirche und Feindliche Welt. Zur dualistischen Auffassungen der Menschenwelt in der Johannesapokalypse," in: Kirche, Fs. G. Bornkamm, ed. D. Lührmann, G. Strecker, Tübingen 1980, 329-349

Scholtissek K., “'Mittelhaber an der Bedrängnis der Königsherrschaft und der Ausdauer in Jesus' (Offb 1, 9). Partizipatorische Ethik der Offenbarung des Johannes," in: Backhaus K. (ed.), Theologie als Vision. Studien zur Johannes-Offenbarung, Stuttgarter Biblische Studien 191, Stuttgart 2001, 172-207.

Schüssler Fiorenza E., "Babylon the Great: A Rhetorical-Political Reading of Revelation 17-18," in: Barr D.L. (ed.), The Reality of Apocalypse. Rhetoric and Politics in the Book of Revelation, SBL Symposium Series, Atlanta 2006, 243-269.

Schüssler Fiorenza E., Revelation. Vision of a Just World, Minneapolis 1991.

Schüssler Fiorenza E., The Book of Revelation. Justice and Judgment, $2^{\text {nd }}$ ed., Minneapolis 1998.

Selvidge M.J., "Reflections on Violence and Pornography. Misogyny in the Apocalypse and Ancient Hebrew Prophecy," in: A Feminist Companion to the Hebrew Bible in the New Testament, ed. A. Brenner, Sheffield 1996, 274-285.

Sikora A.R., "Apokalipsa - przestrogą przed budowaniem świata bez Boga," Questiones Selectae 18(2004), 5-15.

Skaggs R., Doyle T., "Violence in the Apocalypse of John," Currents in Biblical Research 5(2007)2, 220-234.

Söding T., "Heilig, heilig, heilig. Zur politischen Theologie der Johannes-Apokalypse," ZTK 96(1999)1, 49-76.

Spencer R.A., "Violence and Vengeance in Revelation," Review and Expositor 98, 1(2001), 59-75.

Sweet J.P.M., "Maintaining the Testimony of Jesus. The Suffering of Christians in the Revelation of John," in: Suffering and Martyrdom in the New Testament, eds. W. Horbury, B. McNeil, Cambridge 1981, 101-117.

Thomas R.L., “The Imprecatory Prayers of the Apocalypse," Bibliotheca Sacra 126(1969), 123-131.

Vanni U., "Postawa chrześcijanina wobec świata zewnętrznego: prześladowanie w Apokalipsie," Communio [Polish] 7(1987)5, 47-55.

Wawrzyniak A., "Negatywne przykłady kobiet w Apokalipsie wg św. Jana”, in: Kobieta w życiu Kościoła, eds. M. Karczewski, M. Żmudziński, Elbląg 2004, 101-113. 
Wengst K., „Wie lange noch?” Schreien nach Recht und Gerechtigkeit - eine Deutung der Apokalypse des Johannes, Stuttgart 2010.

Wojciechowski M., "Etyka w Apokalipsie św. Jana”, in: Apokaliptyka wczesnego judaizmu i chrześcijaństwa, ed. M.S. Wróbel, Analecta Biblica Lublinensia 6, Lublin 2009, 225-235.

Wolter M., "Christliches Ethos nach der Offenbarung des Johannes,“ in: Studien zur Johannesoffenbarung und ihrer Auslegung, Fs. O. Böcher, ed. F.W. Horn, M. Wolter, Neukirchen 2005, 189-209.

Yarbro Collins A., “The Political Perspective of the Revelation of John,” Journal of Biblical Literature 96(1977), 241-256. 